\title{
Impact of particulate and dissolved material on light absorption properties in a High-Altitude Lake in Tibet, China
}

\author{
Ciren Nima $\cdot$ Børge Hamre $\cdot$ Øyvind Frette $\cdot$ Svein Rune Erga $\cdot$ \\ Yi-Chun Chen - Lu Zhao - Kai Sørensen - Marit Norli • \\ Da-Ren Lu • Qian-Guo Xing • Yao-Ming Ma • Norsang Gelsor • \\ Jakob J. Stamnes
}

Received: 11 May 2015/Revised: 1 October 2015/Accepted: 3 October 2015/Published online: 23 October 2015

(C) Springer International Publishing Switzerland 2015

\begin{abstract}
Ground-based measurements of optical properties have rarely been conducted for lakes located on the Tibetan Plateau (TP). In this study, we analyzed the spectral absorption properties of phytoplankton, non-algal particles, and colored dissolved organic matter sampled in Lake Namtso on the TP in order to obtain the variability in the light absorption properties of each of these three components and the relative contribution of each component. The Chlorophyll- $a$ concentration was found to be very low. The mean value of the spectral slope $S_{280-500}$ for CDOM absorption was found to be $0.036 \mathrm{~nm}^{-1}$, whereas the corresponding mean value for $S_{350-500}$ was found to be $0.015 \mathrm{~nm}^{-1}$, implying that when
\end{abstract}

Handling editor: Alex Elliot

C. Nima $(\square) \cdot$ B. Hamre $~ \varnothing$. Frette · Y.-C. Chen ·

L. Zhao · J. J. Stamnes

Department of Physics and Technology, University of

Bergen, 5020 Bergen, Norway

e-mail: crnmtu@163.com; x.cirennima@ift.uib.no

C. Nima $\cdot$ N. Gelsor

Department of Physics, Tibet University, Tibet

Autonomous Region, Lhasa 850000, China

S. R. Erga

Department of Biology, University of Bergen,

5020 Bergen, Norway

K. Sørensen · M. Norli

Norwegian Institute for Water Research, 0349 Oslo,

Norway comparing spectral slope values with published values, the wavelength range used for deriving them should be considered. Additional peaks were found for phytoplankton sampled in Lake Namtso in the wavelength ranges $310-370$ and $600-640 \mathrm{~nm}$, indicating a significant contribution by accessory pigments to the phytoplankton absorption. The Chlorophyll- $a$ specific absorption coefficients of phytoplankton $\left[a_{\text {phy }}^{*}(\lambda)\right]$ at 440 and $675 \mathrm{~nm}$ in Lake Namtso were found to be much higher than previously reported values, due to the combination of a small package effect and contributions by accessory pigments.

Keywords High-altitude lake $\cdot$ Colored dissolved organic matter $\cdot$ Phytoplankton · Total suspended matter

D.-R. $\mathrm{Lu}$

Institute of Atmospheric Physics, Chinese Academy of Sciences, Beijing 100029, China

Q.-G. Xing

Yantai Institute of Coastal Zone Research, Chinese Academy of Sciences, Yantai 264000, China

Y.-M. Ma

Institute of Tibetan Plateau Research, Chinese Academy of Sciences, Beijing 100000, China 


\section{Introduction}

The Tibetan Plateau (TP) lies in Southwest China and has an average altitude that exceeds $4,000 \mathrm{~m}$ above sea level. Because the TP has the largest storage of snow and ice in the world outside the polar regions, it is sometimes referred to as the 'Third Pole'. The uplift of the TP plays a significant role in the global climate dynamics through its impact on the Asian Monsoon system (Hahn \& Manabe, 1975; An et al., 2001). Numerous lakes and rivers that are distributed across the TP are the sources of major rivers in Asia. On the $\mathrm{TP}$, most lakes having an area larger than $1.0 \mathrm{~km}^{2}$ are located at altitudes above 4,000 m (Jiang \& Huang, 2004) and have a low content of biota because of harsh environmental conditions, such as a short growing season, low temperatures, and low nutrient inputs. Also, lakes on the TP are exposed to high fluxes of UV radiation (Norsang et al., 2009; Norsang et al., 2011; Norsang et al., 2014) due to the natural increase of UV radiation with altitude (Blumthaler et al., 1992; Alexandris et al., 1999) and the existence of a low total ozone column during summer (June-September) (Zhou et al., 2006). UV radiation has impact on both zooplankton and phytoplankton in aquatic ecosystems (Vinebrooke \& Leavitt, 1996; Tartarotti et al., 1999; Helbling et al., 2001; Sommaruga, 2001).

The impact of UV radiation on the biota in lakes on the TP is larger than in lowland lakes. Mountain lakes are highly transparent to UV radiation due to low content of colored dissolved organic matter (CDOM) originating from catchment areas with poorly developed soil and vegetation, implying that UV radiation can penetrate to deep layers of the water column. Also, exposure of CDOM to sunlight can lead to photobleaching and photo-induced degradation, resulting in reduced absorption of UV radiation and visible light (Del Vecchio \& Blough, 2002; Twardowski \& Donaghay, 2002; Brinkmann et al., 2003), which subsequently increases the penetration of harmful UV radiation in aquatic environments.

Recent climate change on the TP is generally characterized by increasing surface air temperatures. As reported in the IPCC Fourth Assessment Report (Parry, 2007), warming on the TP is expected to be well above the global mean. Climatic warming has led to a considerable retreat of glaciers (Wang et al., 2007b), change in soil physical properties as well as degradation of permafrost (Wang et al., 2000) and alpine meadows (Wang et al., 2007a). A temperature increase has a significant impact on glacier melting as well as on soil and vegetation development in catchment areas of lakes, and hence on the input of freshwater and nutrients. All these changes will have impact on the chemical, physical, and biological characteristics of lakes on the TP, and therefore on their optical properties. Studies of the optical properties of lakes are essential to gain a full understanding of climate change impacts. Also, ground-based measurements and analyses of optically significant components in lake water is essential for simulation of light transport in the water column, for construction of bio-optical models, and for remote-sensing-based water quality estimation.

Besides water itself, CDOM and suspended particulate matter are the main components that attenuate light in Case 2 water, such as coastal water, lake water, and river water, through absorption and scattering. The absorption and scattering properties of these optically significant components determine the underwater light distribution, the availability of photosynthetically active radiation (PAR) for primary production, the presence of potentially harmful UV radiation, water clarity, the heat budget of the water body, and the subsurface remote sensing reflectance or water color (Kirk, 2011). Also, they are important for the understanding of photo-related biochemical reactions.

The optical properties of Case 1 water (e.g., openocean water) are well documented (Yentsch, 1962; Bricaud et al., 1981; Bricaud et al., 1995). Openocean water receives less impact from land and human activity, and thus has optical properties that are relatively stable at a large spatial scale. Due to strong impact from land and human activity, Case 2 water has greater variability spatially and temporarily in optical properties (Stedmon et al., 2000; Babin et al., 2003; Twardowski et al., 2004; Ma et al., 2006). Studies of the optical properties of high mountain lakes (Tartarotti et al., 1999; Laurion et al., 2000; Zhou et al., 2005; Tartarotti \& Sommaruga, 2006; Zhang et al., 2009; Zhang et al., 2010; Ficek et al., 2013) have received considerable attention partly because of their harsh environment and partly because remotely located lakes can be considered as sensitive indicators of environmental and climate changes (SommarugaWögrath et al., 1997; Williamson et al., 2008; Adrian et al., 2009). However, such studies have rarely been 
conducted for the lakes located on the world's highest plateau, and ground-based measurements of optical properties of lake water on the TP are rare. Therefore, the aim of this paper is to present measurements and analyses of the absorption properties of optically significant components such as CDOM and particulate matter based on measurements in the third largest lake on the TP. The data presented here are among the first from measurements in lakes on the TP.

In this study, we present data on the absorption properties of CDOM, phytoplankton, and non-algal particles in a large, remote lake located on the TP. We determine the absorption properties of CDOM in the UV and visible spectral regions in terms of the absorption coefficient at 320 and $440 \mathrm{~nm}$, and derive not only the commonly used spectral slope $S_{350-500}$ of CDOM, but also $S_{280-500}$, which we find to be significantly different from $S_{350-500}$, implying that when comparing spectral slope values with earlier published data in the literature, the wavelength range used for deriving them should be taken into account. In addition to the well-known absorption peaks due to Chl- $a$, we find several other peaks in the phytoplankton absorption spectra for Lake Namtso water, and discuss their possible sources. Also, we study the relative contributions of CDOM, phytoplankton, and non-algal particles to the absorption at representative wavelengths of 380, 443, and $675 \mathrm{~nm}$, and find CDOM to be dominant absorbing component at both 380 and $443 \mathrm{~nm}$. At $675 \mathrm{~nm}$, we find phytoplankton to play a dominant role in the light absorption, although nonalgal particles absorb significantly in some cases.

\section{Data and methods}

Study area and secchi depth

Lake Namtso $\left(30^{\circ} 30^{\prime} \mathrm{N}-30^{\circ} 56^{\prime} \mathrm{N}, 90^{\circ} 16^{\prime} \mathrm{E}-91^{\circ} 03^{\prime} \mathrm{E}\right)$ is a mountain lake, located north of Lhasa city at the foot of the North slope of the Nyenchen Tanglha Mountain in central Tibet Autonomous Region (TAR). Lake Namtso (Fig. 1) is the second largest lake in TAR and the highest-situated large lake in the world at an altitude of $4,718 \mathrm{~m}$ above sea level. In 2005 , the lake covered an area of $2,040.9 \mathrm{~km}^{2}$ (Wan et al., 2010) with a drainage basin of about 10,610 $\mathrm{km}^{2}$ (Kang et al., 2011). The catchment-to-lake ratio is about 5 for Lake Namtso. The drainage area of Lake Namtso contains glaciers, alpine permafrost areas, rivers, alpine meadows, and wetlands. The largest depth of Lake Namtso exceeds 90 m (Wang et al., 2009), and the soil in Lake Namtso basin is mainly neutral or slightly alkaline. Lake Namtso has no outflow river, but five main inflow rivers, which enter from west, northwest, southwest, and northeast. The climate in this area is generally characterized as dry and cold. The average annual temperature and annual precipitation recorded at Nam Co (Namtso) station, which is located at the southeast shore of Lake
Fig. 1 Lake Namtso, its drainage area, and inflow rivers. The filled circles denote stations where water samples were collected

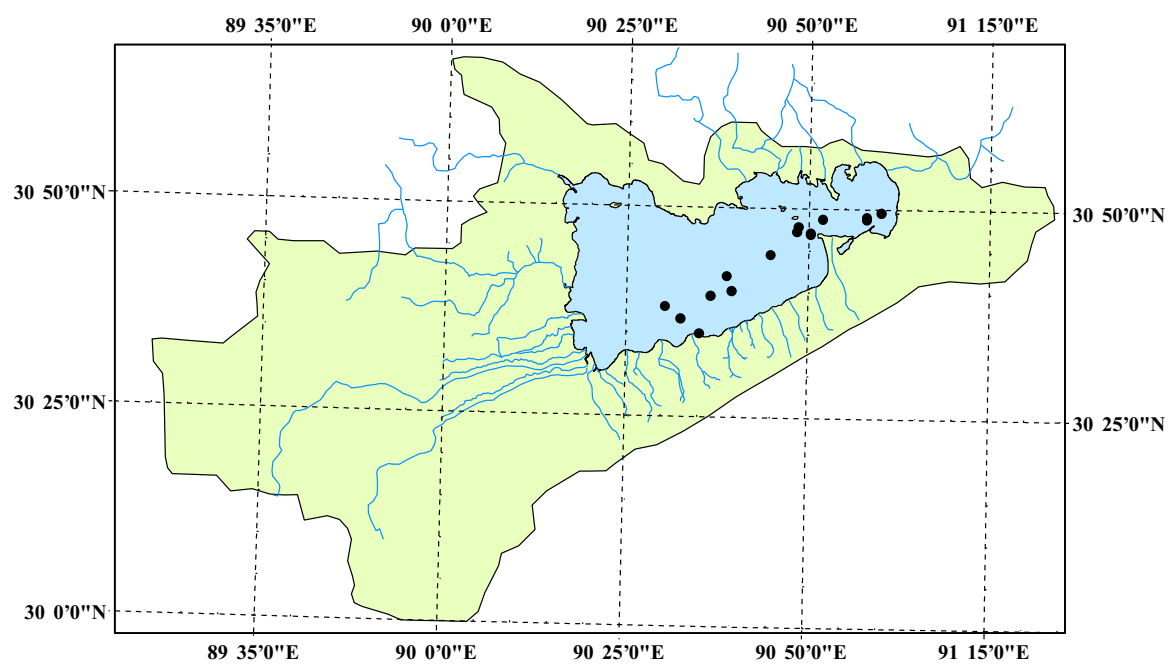


Namtso, are $-0.16{ }^{\circ} \mathrm{C}$ and $414.6 \mathrm{~mm}$ (Kang et al., 2011), respectively. The precipitation mainly occurs during the summer season from June to October (Kang et al., 2011). The landscape is dominated by alpine meadows in this area. The average $\mathrm{pH}$ level for the surface water of this lake is 9.21 (Wang et al., 2009). Lake Namtso is an oligosaline lake with a salinity of $2.0 \mathrm{gl}^{-1}$ (Wu et al., 2006). Based on measurements in August and September, Wang et al. (2009) found that the vertical profiles of water quality parameters (i.e., temperature, $\mathrm{pH}$, dissolved oxygen, and conductivity) in relatively deep parts of Lake Namtso show distinct stratification characteristics, with a well-mixed upper layer ranging from the surface down to 18-20 $\mathrm{m}$ having high and stable values, a middle layer ranging from 20 to $60 \mathrm{~m}$, where the thermocline develops, and a lower or bottom layer below $60 \mathrm{~m}$, which has stable low temperatures. Analyses of the ice cover of Lake Namtso based on MODIS data show that detectable ice appears in early January and disappears in middle of May (Kropáček et al., 2013). In the winters of 2008 and 2009, the ground-measured thickness of the ice cover for the eastern part of Lake Namtso varied between 24 and 59 cm (Ye et al., 2011).

We visited a total of 15 stations in Lake Namtso, as shown in Table 1 and indicated by the filled circles in Fig. 1. At most stations, water samples were collected from three depths, i.e., close to the surface, at half the Secchi depth, and at the full Secchi depth. Detailed information about the stations is given in Table 1.

Determination of CDOM absorption coefficient and spectral slope

Water samples were filtered through Whatman Polycarbonate filters (diameter $47 \mathrm{~mm}$, pore size $0.22 \mu \mathrm{m}$ ) at low vacuum pressure on the day they were collected, and the filtrate was collected in pre-washed bottles. The bottles were first rinsed three times with filtered sample water to minimize the possibility of contamination. The CDOM samples were stored in a refrigerator until analysis except during transportation. During transportation, all samples were stored in boxes with ice bags, and the total transportation time was less than $18 \mathrm{~h}$. Prior to analysis, the CDOM samples and Milli-Q water were acclimated to room temperature. The absorbance spectra were recorded at wavelengths in the range from 200 to $900 \mathrm{~nm}$ with $2 \mathrm{~nm}$ increments using a dual-beam Shimadzu spectrophotometer (UV-1800) equipped with a $10 \mathrm{~cm}$ quartz cuvette. Baseline data were obtained by filling Milli-Q water both in the sample and reference cells, and baseline correction was done by subtracting the offset from each sample spectrum. Absorbance data were converted to absorption coefficients using
Table 1 Stations (St.), locations, secchi depths, and dates for measurements in Lake Namtso

\begin{tabular}{llcl}
\hline St. & Location & Secchi depth $(\mathrm{m})$ & Date \\
\hline 1 & $30^{\circ} 49.034^{\prime} \mathrm{N} 90^{\circ} 57.987^{\prime} \mathrm{E}$ & 9 & $07 / 26 / 2013$ \\
2 & $30^{\circ} 48.755^{\prime} \mathrm{N} 90^{\circ} 51.936^{\prime} \mathrm{E}$ & 9 & $07 / 27 / 2013$ \\
3 & $30^{\circ} 47.103^{\prime} \mathrm{N} 90^{\circ} 50.277^{\prime} \mathrm{E}$ & 11 & $07 / 29 / 2013$ \\
4 & $30^{\circ} 44.407^{\prime} \mathrm{N} 90^{\circ} 44.803^{\prime} \mathrm{E}$ & 11 & $07 / 30 / 2013$ \\
5 & $30^{\circ} 41.796^{\prime} \mathrm{N} 90^{\circ} 38.817^{\prime} \mathrm{E}$ & 10 & $07 / 31 / 2013$ \\
6 & $30^{\circ} 49.607^{\prime} \mathrm{N} 91^{\circ} 00.072^{\prime} \mathrm{E}$ & 10 & $08 / 17 / 2014$ \\
7 & $30^{\circ} 48.913^{\prime} \mathrm{N} 90^{\circ} 57.990^{\prime} \mathrm{E}$ & 10 & $08 / 17 / 2014$ \\
8 & $30^{\circ} 47.040^{\prime} \mathrm{N} 90^{\circ} 50.267^{\prime} \mathrm{E}$ & 12 & $08 / 18 / 2014$ \\
9 & $30^{\circ} 47.801^{\prime} \mathrm{N} 90^{\circ} 48.588^{\prime} \mathrm{E}$ & 12 & $08 / 18 / 2014$ \\
10 & $30^{\circ} 48.202^{\prime} \mathrm{N} 90^{\circ} 48.383^{\prime} \mathrm{E}$ & 12 & $08 / 19 / 2014$ \\
11 & $30^{\circ} 40.032^{\prime} \mathrm{N} 90^{\circ} 39.513^{\prime} \mathrm{E}$ & 10 & $08 / 20 / 2014$ \\
12 & $30^{\circ} 39.449^{\prime} \mathrm{N} 90^{\circ} 36.614^{\prime} \mathrm{E}$ & 10 & $08 / 20 / 2014$ \\
13 & $30^{\circ} 36.671^{\prime} \mathrm{N} 90^{\circ} 32.526^{\prime} \mathrm{E}$ & 10 & $08 / 16 / 2014$ \\
14 & $30^{\circ} 38.092^{\prime} \mathrm{N} 90^{\circ} 30.357^{\prime} \mathrm{E}$ & 10 & $08 / 16 / 2014$ \\
15 & $30^{\circ} 34.619^{\prime} \mathrm{N} 90^{\circ} 35.135^{\prime} \mathrm{E}$ & 9 & $09 / 14 / 2012$ \\
\hline
\end{tabular}


$a_{\mathrm{g}, \mathrm{m}}(\lambda)=2.303 O D(\lambda) / \ell$,

where the subscript $g$ stands for CDOM, $a_{\mathrm{g}, \mathrm{m}}(\lambda)$ and $O D(\lambda)$ are the measured absorption coefficient $\left(\mathrm{m}^{-1}\right)$ and absorbance, respectively, at wavelength $\lambda$, and $\ell$ is the path length in $(\mathrm{m})(\ell=0.1 \mathrm{~m})$. In Eq. (1), the number 2.303 (i.e., $\ln 10$ ) is the conversion factor between the base 10 logarithm used for absorbance and the natural logarithm used for the absorption coefficient. The absorption coefficient was corrected for scattering by residual particles in the CDOM samples using (Bricaud et al., 1981)

$a_{\mathrm{g}}(\lambda)=a_{\mathrm{g}, \mathrm{m}}(\lambda)-a_{\mathrm{g}, \mathrm{m}}(720) \times(720 / \lambda)$,

where $a_{\mathrm{g}}(\lambda)$ is the corrected, and $a_{\mathrm{g}, \mathrm{m}}(720)$ is the measured absorption coefficient at $\lambda=720 \mathrm{~nm}$. As discussed by several authors (Stedmon et al., 2000; Twardowski et al., 2004), applying a natural logarithm transformation to absorption spectra before applying a regression fitting, one may change the weighting of the data points and thus introduce errors in the determination of the slope $S$. Therefore, the slopes $S$ of the measured CDOM absorption spectra were determined by fitting them directly to the following equation (Bricaud et al., 1981)

$a_{\mathrm{g}}(\lambda)=a_{\mathrm{g}}\left(\lambda_{0}\right) \exp \left[-S\left(\lambda-\lambda_{0}\right)\right]$,

where $a_{\mathrm{g}}(\lambda)$ and $a_{\mathrm{g}}\left(\lambda_{0}\right)$ are the absorption coefficients at an observed wavelength $\lambda$ and at a reference wavelength $\lambda_{0}$, respectively. The absorption coefficient $a_{\mathrm{g}}\left(\lambda_{0}\right)$ at the reference wavelength $\lambda_{0}$ is used to characterize the CDOM concentration in a specific type of natural water. In this study, the reference wavelength $\lambda_{0}$ was set to 320 or $440 \mathrm{~nm}$. The spectral slope $S\left(\mathrm{~nm}^{-1}\right)$, which is independent of the choice of $\lambda_{0}$, indicates how rapidly the absorption decreases with increasing wavelength.

The natural logarithm of the measured absorption spectrum for different CDOM samples of Lake Namtso water is shown in Fig. 2a. It is clearly seen that these curves cannot be described by Eq. (3) with a single spectral slope covering both UV and visible spectral regions. Therefore, two sets of CDOM spectral slopes are given in this paper, denoted by $S_{280-500}$ and $S_{350-500}$, respectively. $S_{280-500}$ was derived using the wavelength range $280-500 \mathrm{~nm}$ for fitting, while $S_{350-500}$ was derived for the wavelength range $350-500 \mathrm{~nm}$. Figure $2 \mathrm{~b}$ shows a semi-log plot of

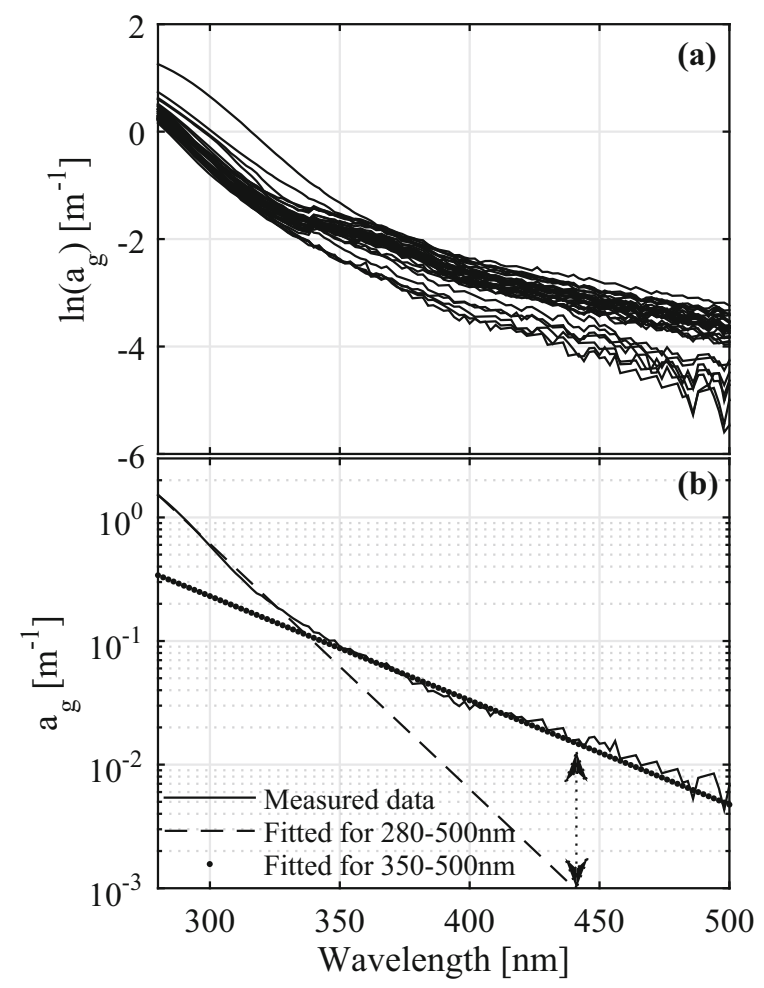

Fig. 2 a Natural log-transformed plot of all measured CDOM absorption spectra. b Semi-log plot of one of the measured CDOM absorption spectra in (a) together with nonlinear fits based on the exponential model in Eq. (3) for the wavelength ranges $280-500$ and $350-500 \mathrm{~nm}$. The double vertical arrow at $440 \mathrm{~nm}$ indicates the difference between measured and fitted data obtained for the wavelength range $280-500 \mathrm{~nm}$

one of the measured absorption spectra for CDOM samples obtained from Lake Namtso together with nonlinear fits based on the exponential model in Eq. (3) for the wavelength ranges 280-500 and 350$500 \mathrm{~nm}$. Figure $2 \mathrm{~b}$ indicates that the derived absorption coefficient at 320 or $440 \mathrm{~nm}$ will depend on the wavelength range used to obtain the nonlinear fit. Therefore, in this study, $a_{\mathrm{g}}(320)$ was derived using the wavelength range $280-500 \mathrm{~nm}$ to obtain the nonlinear fit, while $a_{\mathrm{g}}(440)$ was derived using the wavelength range $350-500 \mathrm{~nm}$.

Helms et al. (2008) defined the spectral slope ratio $S_{\mathrm{R}}$ as the ratio of $S_{275-295}$ to $S_{350-400}$, where $S_{275-295}$ and $S_{350-400}$ are the spectral slopes determined using linear regression of the log-transformed absorption spectra for the wavelength ranges of 275-295 and $350-400 \mathrm{~nm}$, respectively. They pointed out that $S_{R}$ is useful for characterizing $\mathrm{CDOM}$ in natural water. 
Helms et al. (2008) found $S_{R}$ values to be larger than 1 for marine CDOM samples, but smaller than 1 for terrestrially dominated CDOM samples. Also, they found the $S_{R}$ value to be related to the CDOM molecular weight (MW) and to photochemically induced shifts in the MW. Thus, upon light exposure of CDOM they found the percentage of CDOM in the low-molecular weight (LMW) $(<1,000 \mathrm{Da})$ fraction to increase, and the percentage in the high-molecularweight $(\mathrm{HMW})(>1,000 \mathrm{Da})$ fraction to decrease, resulting in an increase of the $S_{R}$ value. In our study, we use $S_{R}$ to characterize changes in the spectral shape of CDOM.

Determination of particle absorption coefficients

In order to determine absorption coefficients for particulate matter, $800-1150 \mathrm{ml}$ of sample water was filtered through a $25 \mathrm{~mm}$ diameter glass fiber filter (Whatman, GF/F) at low vacuum pressure. Each sample filter for total suspended matter (TSM) or Chl$a$ was preserved in a small Petri dish, wrapped with aluminum foil, and stored in a freezer before transportation from Tibet to Norway. After transportation, all samples were stored at a temperature of $-80{ }^{\circ} \mathrm{C}$ until analysis. The absorption spectrum of the particles retained on the filter was determined according to the Transmittance-Reflectance method (Tassan \& Ferrari, 2002). The transmittance and reflectance of the sample filter were measured for wavelengths between 280 and $900 \mathrm{~nm}$ with $2 \mathrm{~nm}$ increments using a dual-beam Shimadzu spectrophotometer equipped with a $60 \mathrm{~mm}$ integrating sphere (UV-2401 PC). The absorbance $O D_{\mathrm{s}}$ of the particles retained on the filter was converted to an equivalent absorbance $O D_{\text {sus }}$ of the suspension using (Tassan \& Ferrari, 2002)

$$
O D_{\text {sus }}(\lambda)=0.423 O D_{\mathrm{s}}(\lambda)+0.479 O D_{\mathrm{s}}^{2}(\lambda) .
$$

The absorption coefficient $a_{\mathrm{p}}(\lambda)$ for all particles was then derived from

$a_{\mathrm{p}}(\lambda)=2.303 \frac{O D_{\text {sus }}(\lambda)}{X}$,

where $X(\mathrm{~m})$ is the ratio of the volume of the filtered water sample to the filter clearance area.

Bleaching of pigmented particles was performed using a $0.1 \%$ active chlorine solution of sodium hypochlorite $(\mathrm{NaClO})$ in accordance with the
REVAMP protocol (Tilstone et al., 2002). The absorption coefficient $a_{\text {phy }}(\lambda)$ for pigmented particles (referred to as phytoplankton in this study) was then derived by subtracting the absorption coefficient $a_{\mathrm{NAP}}(\lambda)$ for non-pigmented particles (commonly referred to as non-algal particles (NAP) (Bricaud et al., 1998; Babin et al., 2003)) obtained after bleaching from the absorption coefficient $a_{\mathrm{p}}(\lambda)$ for all particles. Data from 38 samples were used in this study. In order to agree with the terminology used in most studies (Bricaud et al., 1998; Babin et al., 2003), non-pigmented particles will hereafter be called nonalgal particles (NAP). The following equation was fitted to the absorption coefficients for non-algal particles:

$a_{\mathrm{NAP}}(\lambda)=a_{\mathrm{NAP}}\left(\lambda_{0}\right) \exp \left[-S_{\mathrm{NAP}}\left(\lambda-\lambda_{0}\right)\right]$,

where $a_{\mathrm{NAP}}(\lambda)$ and $a_{\mathrm{NAP}}\left(\lambda_{0}\right)$ are the absorption coefficients at an observed wavelength $\lambda$ and at a reference wavelength $\lambda_{0}$, respectively. In this study, the reference wavelength $\lambda_{0}$ was set to $443 \mathrm{~nm}$. The spectral slope $S_{\mathrm{NAP}}\left(\mathrm{nm}^{-1}\right)$ was determined by fitting the measured absorption spectra for non-algal particles directly to Eq. (6) using data within the wavelength range 350-600 $\mathrm{nm}$.

Determination of total suspended matter (TSM) concentration

In order to determine the TSM concentration, 2000-3000 ml water samples were filtered through pre-weighed Whatman $47 \mathrm{~mm} \mathrm{GF} / \mathrm{F}$ filters to obtain TSM samples. The pre-ashed, pre-washed, and preweighed GF/F filters were prepared in accordance with the REVAMP protocol (Tilstone et al., 2002). The TSM samples were stored in a freezer at $-80{ }^{\circ} \mathrm{C}$ until analysis. The filters were dried in an oven at $75{ }^{\circ} \mathrm{C}$ for $24 \mathrm{~h}$, and then cooled in a desiccator and weighed on a Mettler Toledo MT5 micro-balance.

\section{Determination of Chl- $a$ concentration}

In order to determine the Chl- $a$ concentration, 800-1150 $\mathrm{ml}$ water samples were filtered through 25 or $47 \mathrm{~mm}$ Whatman GF/F filters on the day of collection. After transportation, all samples were stored in a freezer at $-80{ }^{\circ} \mathrm{C}$. Chl- $a$ concentrations were determined using high pressure liquid chromatography (HPLC) with the 
method of Wright (1991). The HPLC (Waters 2695 Separations module) was calibrated using standards (DHI) and routinely quality controlled with in-house standards. The pigments were extracted in $5 \mathrm{ml} 90 \%$ acetone in a dark room at room temperature (20-25 ${ }^{\circ} \mathrm{C}$ ) for $4 \mathrm{~h}$. The samples were then sonicated for $20 \mathrm{~s}$ for better extraction before $1 \mathrm{ml}$ was transferred to $2 \mathrm{ml}$ vials (Chromacol) and kept in the dark at 4 $( \pm 2){ }^{\circ} \mathrm{C}$ in the injector chamber. Chl- $a$ was quantified using a response factor from multipoint regression of diluted standards (DHI) with known concentrations calculated from the measured absorption in a spectrophotometer with the recommended extinction coefficient (Jeffrey \& Humphrey, 1975).

\section{Results}

TSM and Chl- $a$ concentration

Secchi depth data from 2013 and 2014 (Table 1) show the transparency of Lake Namtso water to be higher in the middle of the lake than in its eastern and western parts. Using empirical relations (Kirk, 2011), one finds the measured Secchi depths in Lake Namtso to correspond to downward vertical attenuation coefficients $K_{\mathrm{d}}(\mathrm{PAR})$ for photosynthetically available radiation (PAR) in the range $0.12-0.16 \mathrm{~m}^{-1}$ and to euphotic depths in the range $29-38 \mathrm{~m}$. The observed TSM and Chl- $a$ concentrations of Lake Namtso water are shown in Fig. 3, and the corresponding variation ranges and mean values are shown in Table 2.

All samples in our study were collected down to the Secchi depth, which at the deepest was $12 \mathrm{~m}$, and thus well within the euphotic zone (29-38 m). The Chl$a$ concentration was found to be very low in Lake Namtso. It varied between 0.007 and $0.17 \mu \mathrm{gl}^{-1}$ with a mean value of $0.08 \mu \mathrm{gl}^{-1}$, and in most cases, it was higher at the surface than at the half or full Secchi depth. In general, the Chl- $a$ concentration was lower for the samples collected in late July 2013 (see St. 2St. 5 in Fig. 3a) than for the samples collected in the middle of August 2014 (see St. 6-St. 14).

The TSM concentrations in Lake Namtso water varied between 0.74 and $2.85 \mathrm{mgl}^{-1}$, with mean value and standard deviation (STD) given by $(1.11 \pm 0.33)$ $\mathrm{mgl}^{-1}$. Except for a sample that was collected at St. 15 (see Table 1) at a depth of $6 \mathrm{~m}$, for which the TSM

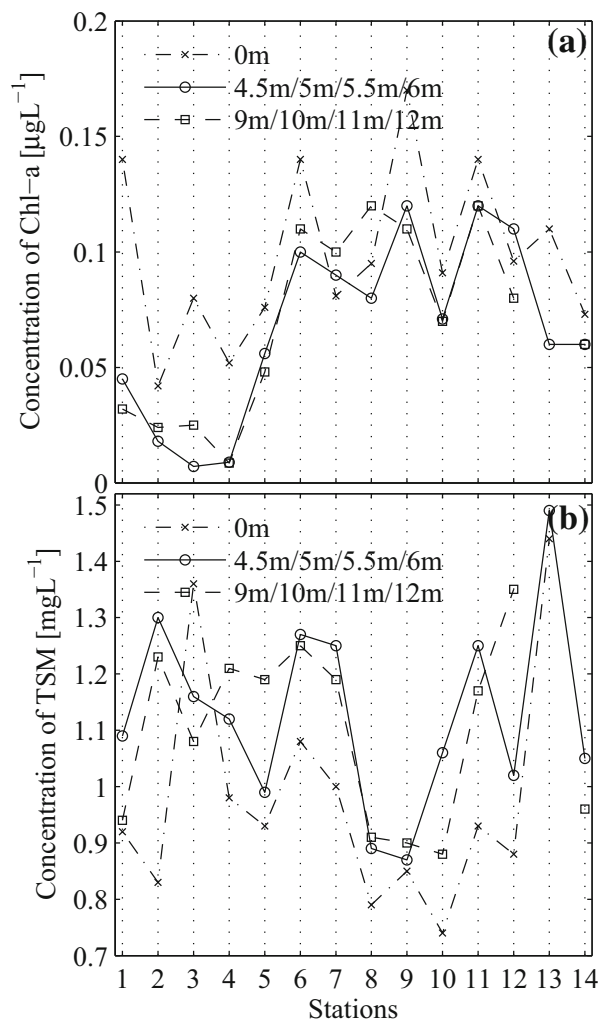

Fig. 3 Variation of TSM and Chl- $a$ concentration between stations in Lake Namtso. St. 1-St. 5 correspond to water samples taken in late July, 2013, while the other stations correspond to water samples taken in the middle of August, 2014. The station numbers are shown in Table 1. Note that in both (a) and (b), St. 15 is not included since no Chl- $a$ concentration data are available for this station

concentration was $2.85 \mathrm{mgl}^{-1}$, the TSM concentration was found to be lower than $1.5 \mathrm{mgl}^{-1}$. The high TSM value of $2.85 \mathrm{mgl}^{-1}$ may be due to bottom sediment resuspension since St. 15 is close to the shore, where the water is quite shallow. In most cases, the TSM concentration was found to be lower at the surface. High values of the Secchi depth correspond to the low values of the TSM concentration found at St. 8-10, as shown in Table 1 and Fig. 3b. The TSM concentration did not show a similar variation as the Chl- $a$ concentration between samples collected in late July 2013 and in the middle of August 2014.

A scatter plot of TSM versus Chl- $a$ (not shown) including all Lake Namtso samples $(N=40)$ resulted in a correlation coefficient of -0.22 , implying a very weak correlation. Similarly, Secchi depths were inversely correlated with the TSM concentration 
Table 2 Water properties of Lake Namtso: TSM and Chl$a$ concentrations, CDOM absorption spectral slopes $S_{280-500}$ and $S_{350-500}$, spectral slope ratio $S_{\mathrm{R}}$ of $S_{275-295}$ to $S_{350-400}$, CDOM absorption coefficients at $320 \mathrm{~nm}\left[a_{\mathrm{g}}(320)\right]$ and $440 \mathrm{~nm}$

\begin{tabular}{lllllllllll}
\hline & $\begin{array}{l}\text { TSM } \\
\left(\mathrm{mgl}^{-1}\right)\end{array}$ & $\begin{array}{l}\text { Chl- } a \\
\left(\mu l^{-1}\right)\end{array}$ & $\begin{array}{l}S_{280-500} \\
\left(\mathrm{~nm}^{-1}\right)\end{array}$ & $\begin{array}{l}S_{350-500} \\
\left(\mathrm{~nm}^{-1}\right)\end{array}$ & $S_{\mathrm{R}}$ & $\begin{array}{l}a_{\mathrm{g}}(320) \\
\left(\mathrm{m}^{-1}\right)\end{array}$ & $\begin{array}{l}a_{\mathrm{g}}(440) \\
\left(\mathrm{m}^{-1}\right)\end{array}$ & $\begin{array}{l}a_{\mathrm{p}}(320) \\
\left(\mathrm{m}^{-1}\right)\end{array}$ & $\begin{array}{l}a_{\mathrm{p}}(440) \\
\left(\mathrm{m}^{-1}\right)\end{array}$ & $\begin{array}{l}a_{\mathrm{phy}}(440) \\
\left(\mathrm{m}^{-1}\right)\end{array}$ \\
\hline Max & 2.85 & 0.17 & 0.046 & 0.023 & 3.07 & 0.89 & 0.065 & 0.209 & 0.086 & 0.044 \\
Min & 0.74 & 0.007 & 0.030 & 0.012 & 1.09 & 0.22 & 0.015 & 0.049 & 0.019 & 0.010 \\
Mean & 1.11 & 0.08 & 0.036 & 0.015 & 2.28 & 0.33 & 0.041 & 0.097 & 0.039 & 0.023 \\
STD & 0.33 & 0.04 & 0.004 & 0.002 & 0.39 & 0.12 & 0.012 & 0.038 & 0.014 & 0.007 \\
\hline
\end{tabular}

STD standard deviation
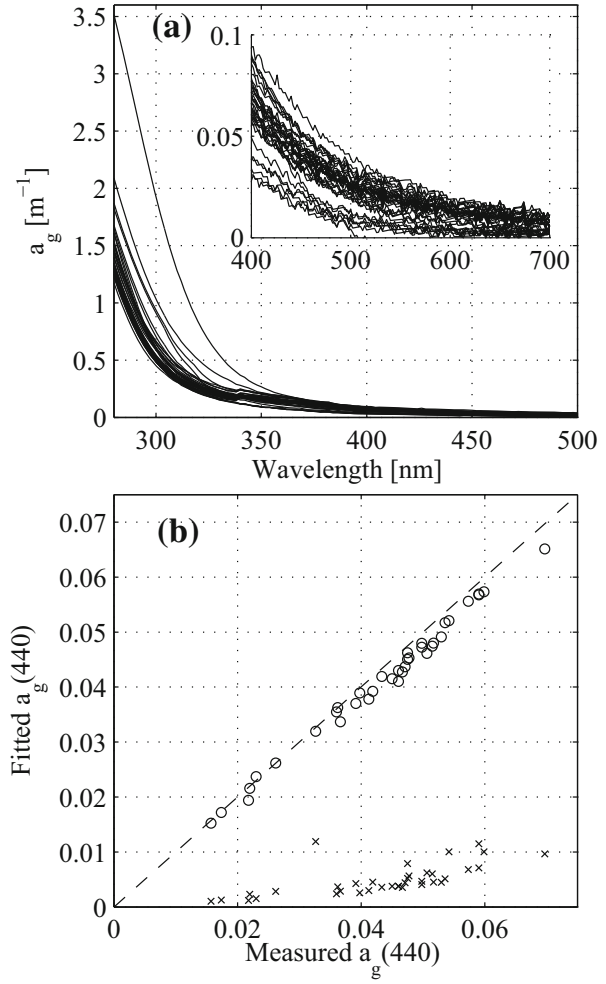

Fig. 4 a CDOM absorption spectra for Lake Namtso water samples collected in 2013 and 2014. b Scatter plot of the fitted absorption coefficient $a_{\mathrm{g}}(440)$ for CDOM derived using the range $280-500 \mathrm{~nm}$ for fitting (denoted by ' $x$ ') and the range 350 $500 \mathrm{~nm}$ (denoted by ' $o$ ') against the measured $a_{\mathrm{g}}(440)$

averaged over depths resulting in a correlation coefficient of 0.57 . The correlation coefficient between the Chl- $a$ concentration averaged over depths at each station and the Secchi depth was found to be 0.21 .
[ $\left.a_{\mathrm{g}}(440)\right]$, total suspended matter absorption coefficients at 320 $\mathrm{nm}\left[a_{\mathrm{p}}(320)\right]$ and $440 \mathrm{~nm}\left[a_{\mathrm{p}}(440)\right]$, and phytoplankton absorption coefficient at $440\left[a_{\text {phy }}(440)\right]$ 
are much lower than the measured values, while the $a_{\mathrm{g}}(440)$ values derived by using the wavelength range $350-500 \mathrm{~nm}$ are very close to the measured values.

The absorption coefficient at a reference wavelength is commonly used as a measure of the CDOM concentration. Figure 5 shows the statistical distribution of the CDOM absorption coefficients at $440 \mathrm{~nm}$ $\left[a_{\mathrm{g}}(440)\right]$ and $320 \mathrm{~nm}\left[a_{\mathrm{g}}(320)\right]$ as well as of the spectral slopes $S_{280-500}$ and $S_{350-500}$ for Lake Namtso water. It follows from Fig. 5 that the absorption coefficients at $440 \mathrm{~nm}\left[a_{\mathrm{g}}(440)\right]$ were much smaller than at $320 \mathrm{~nm}\left[a_{\mathrm{g}}(320)\right]$. The former varied between 0.015 and $0.065 \mathrm{~m}^{-1}$ with mean value and STD given by $(0.041 \pm 0.012) \mathrm{m}^{-1}$, and the latter varied between 0.22 and $0.89 \mathrm{~m}^{-1}$ with mean value and STD given by $(0.33 \pm 0.12) \mathrm{m}^{-1}$, as shown in Table 2. The CDOM absorption spectral slope $S_{280-500}$ for Lake Namtso varied from 0.030 to $0.046 \mathrm{~nm}^{-1}$ with mean value and STD given by $(0.036 \pm 0.004) \mathrm{nm}^{-1}$, and the spectral slope $S_{350-500}$ varied between 0.012 and $0.023 \mathrm{~nm}^{-1}$ with mean value and STD given by $(0.015 \pm 0.002)$ $\mathrm{nm}^{-1}$, as shown in Table 2 and Fig. $5 \mathrm{c}$, d.

According to Helms et al. (2008), the spectral ratio $S_{\mathrm{R}}=S_{275-295} / S_{350-400}$ can be used to characterize CDOM, such as its molecular weight or source. The $S_{\mathrm{R}}$ values for Lake Namtso water were found to vary between 1.09 and 3.07 with a mean value of 2.28 , and $98 \%$ of the $S_{R}$ values were found to be higher than 1.5 . We found the variation of $a_{\mathrm{g}}(443)$ for Lake Namtso water to be quite similar to the variation of the Chl$a$ concentration with a correlation coefficient of 0.72 $\left(r^{2}=0.52\right)$, and the regression equation between these two quantities can be written as $a_{\mathrm{g}}(443)=0.18<\mathrm{chl}>$ +0.024 . In most cases, both $a_{\mathrm{g}}(443)$ and the Chl$a$ concentration were found to be higher in August 2014 than in July 2013.

Total suspended matter absorption

Figure 6 shows absorption spectra for TSM $\left[a_{\mathrm{p}}(\lambda)\right]$, phytoplankton $\left[a_{\text {phy }}(\lambda)\right]$, and non-algal particles $\left[a_{\mathrm{NAP}}(\lambda)\right]$ of Lake Namtso water. The TSM absorption includes contributions from both phytoplankton and non-algal particles. Within the wavelength range between 310 and $700 \mathrm{~nm}$, the TSM absorption generally decreases as the wavelength increases (Fig. 6a), and the peaks around $676 \mathrm{~nm}$, which are mainly due to Chl- $a$ absorption, are almost

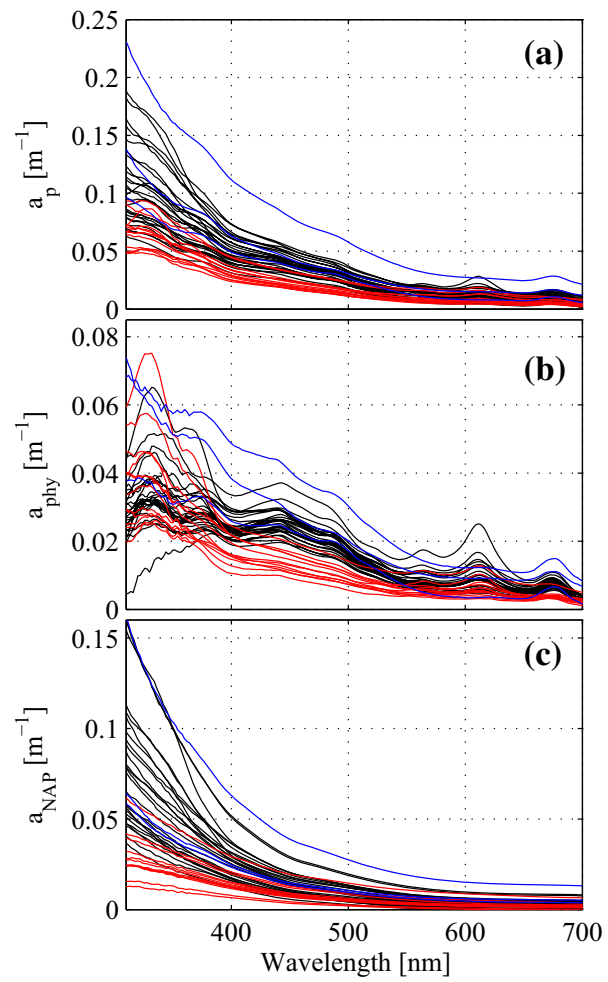

Fig. 6 Absorption spectra for a TSM, b phytoplankton, and c non-algal particles for Lake Namtso. Blue, red, and black curves represent samples collected in 2012, 2013, and 2014, respectively. Note the difference in scale on the vertical axis between (a), (b), and (c)

unnoticeable because the phytoplankton absorption at $676 \mathrm{~nm}$ is low relative to the NAP absorption. Peaks in the wavelength range between 600 and 640 were observed for samples collected in late July 2013 and in the middle of August 2014. The strongest absorption spectrum in Fig. 6a (blue curve) corresponds to the sample with the highest TSM concentration, i.e., 2.85 $\mathrm{mgl}^{-1}$. The TSM absorption coefficient at $440 \mathrm{~nm}$ [ $\left.a_{\mathrm{p}}(440)\right]$ was found to vary from 0.019 to $0.086 \mathrm{~m}^{-1}$ with mean value and STD given by $(0.039 \pm 0.014)$ $\mathrm{m}^{-1}$. Typical peaks and shoulders around 440 and 676 $\mathrm{nm}$ due to the absorption by Chl- $a$ were found in all samples, as seen in Fig. 6b. Generally these peaks and shoulders for the samples collected in late July 2013 (red curves) are consistently smaller than for the samples collected in the middle of August 2014 (black curves). Except for these typical peaks and shoulders, there are peaks in the UV spectral region between 310 and $370 \mathrm{~nm}$ and in the visible region between 600 and 
Table 3 Optical properties (the concentrations of TSM and Chl- $a$ and the vertical attenuation coefficient for PAR) of water in several lakes

\begin{tabular}{lllllll}
\hline & $\begin{array}{l}\text { L. Namtso } \\
\text { TP }\end{array}$ & $\begin{array}{l}\text { L. Taupo } \\
\text { New Zealand }\end{array}$ & $\begin{array}{l}\text { L. Tahoe } \\
\text { USA }\end{array}$ & $\begin{array}{l}\text { Crater L. Oregon } \\
\text { USA }\end{array}$ & $\begin{array}{l}\text { North Basin of L. Biwa } \\
\text { Japan }\end{array}$ & $\begin{array}{l}\text { L. Puma Yumco } \\
\text { TP }\end{array}$ \\
\hline TSM $\left[\mathrm{mgl}^{-1}\right]$ & $0.74-2.85$ & $0.35-1.60^{\mathrm{a}}$ & $x$ & $x$ & $0.8-5.5^{\mathrm{f}}$ & $x$ \\
& $(1.11)$ & $(0.59)^{\mathrm{a}}$ & $x$ & $x$ & $(1.58)^{\mathrm{f}}$ & $x$ \\
$\mathrm{Chl}-a\left[\mu \mathrm{gl}^{-1}\right]$ & $0.007-0.17$ & $0.82-2.59^{\mathrm{a}}$ & $0.70^{\mathrm{c}}$ & $x$ & $1.4-2.6^{\mathrm{f}}$ & $0.05^{\mathrm{g}}$ \\
& $(0.08)$ & $(1.14)^{\mathrm{a}}$ & & $(1.92)^{\mathrm{f}}$ & $0.28^{\mathrm{f}}$ & $0.15^{\mathrm{h}}$ \\
$K_{\mathrm{d}}(\mathrm{PAR})\left[\mathrm{m}^{-1}\right]$ & $0.12-0.16$ & $0.14^{\mathrm{b}}$ & $0.063-0.103^{\mathrm{d}}$ & $0.04-0.11^{\mathrm{e}}$ & & \\
& $(0.14)$ & & $(0.077)^{\mathrm{d}}$ & $(0.052)^{\mathrm{e}}$ & & \\
\hline
\end{tabular}

The values are shown either as a variation range, where extreme values are separated by '-', and where the mean value, if available, is given in parenthesis. In some cases only one available value is given. The symbol ' $x$ ' indicates that data were not found.

a Belzile et al. (2004)

b Davies-Colley et al. (1984)

c Tahoe Environmental Research Center (2015)

d Rose et al. (2009)

e Hargreaves et al. (2007)

${ }^{f}$ Belzile et al. (2002)

g Liu et al. (2009)

h Mitamura et al. (2003)

$640 \mathrm{~nm}$ in the absorption spectra for most samples from Lake Namtso.

For the samples collected in late July 2013, it was observed that the peaks in the range of 310-370 nm decrease from St. 1 to St. 5, except at St. 3, which is close to a tourist site. Also, these peaks were present predominantly in the surface samples. As the water depth increased, they became less prominent. However, the samples obtained from Lake Namtso in the middle of August 2014 did not show such a clear pattern.

It is also seen from Fig. 6b that the absorption spectra for phytoplankton samples collected in late July 2013 (red curves) consistently decrease exponentially as the wavelength increases from 400 to 550 nm.

Absorption spectra for non-algal particles in Lake Namtso are presented in Fig. 6c, which shows that these spectra follow similar exponential decay curves as CDOM absorption spectra but with a smaller spectral slope. The absorption coefficient at $443 \mathrm{~nm}$ for non-algal particles $\left[a_{\mathrm{NAP}}(443)\right]$ varied between 0.004 and 0.043 with mean value and STD given by $(0.015 \pm 0.008) \mathrm{m}^{-1}$. The corresponding spectral slope $S_{\mathrm{NAP}}$ varied between 0.008 and 0.016 with mean value and STD given by $(0.011 \pm 0.002) \mathrm{nm}^{-1}$.

\section{Discussion}

During our field campaigns in Lake Namtso, the Chl$a$ concentration was found to be very low [0.007-0.17 $\left.\mu \mathrm{gl}^{-1}\right]$, although measurements were done during the productive season (May-September). For the surface samples from Lake Namtso, the mean value of the Chl- $a$ concentration was found to be $0.1 \mu \mathrm{gl}^{-1}$. Liu et al. (2010) found a similarly low value of $0.46 \mu \mathrm{gl}^{-1}$ in September 2005 for surface samples taken close to the shore and measured using a Fluoro spectrophotometer. The low Chl- $a$ concentrations in both studies are characteristic of an ultraoligotrophic lake $[<c h l>$ $<1 \mathrm{gl}^{-1}$ (Vollenweider, 1982)] and make the results of this study comparable to those of studies in other lakes with very low Chl- $a$ concentration values, such as (see Table 3) Lake Taupo, New Zealand (Belzile et al., 2004), Lake Tahoe, USA (Tahoe Environmental Research Center, 2015), north basin of Lake Biwa, Japan (Belzile et al., 2002), as well as in lakes located 
above 4,000 $\mathrm{m}$ on the Yungui Plateau, China (Zhang et al., 2010) and Lake Puma Yumco, China (Liu et al., 2009), the latter being located on the TP. The low Chl$a$ concentrations in Lake Namtso water can be related to harsh environmental conditions with a short growing season [normally from mid-May until midSeptember (Dorji et al., 2013)], low temperatures [average annual temperature of $-0.16^{\circ} \mathrm{C}$ (Kang et al., 2011)], and high UV exposure [UV index above 15 on TP (Norsang et al., 2014)]. The high Chl- $a$ concentrations observed at the surface of St. 1 in late July 2013 compared to those observed at St. 2-St. 5 in the same period (see Fig. 3a) may be due partly to the effect of the river inlet.

The values of $K_{d}(P A R)$ found in the present study are quite similar to previously reported values of $0.11-$ $0.13 \mathrm{~m}^{-1}$ (Kang et al., 2011). Also, the estimated values of $K_{d}(P A R)$ for Lake Namtso are quite similar to the values found for Lake Puma Yumco (Mitamura et al., 2003) and Lake Taupo (Davies-Colley et al., 1984), but higher than the values found for Lake Tahoe (Rose et al., 2009) and Crater Lake Oregon (Hargreaves et al., 2007), and smaller than the value found for north basin of Lake Biwa (Belzile et al., 2002), as shown in Table 3.

The very low CDOM absorption for Lake Namtso water at visible wavelengths could result from a combination of several factors. The CDOM absorption is naturally low in the visible spectral region, and the CDOM abundance in Lake Namtso water is expected to be low because of poor development of the vegetation due to high altitude and harsh environment. Furthermore, Lake Namtso has a higher exposure of solar radiation than lowland lakes, and the exposure of CDOM to solar radiation causes photobleaching (Del Vecchio \& Blough, 2002; Twardowski \& Donaghay, 2002; Brinkmann et al., 2003), the rate of which is found to be different for different spectral regions. For CDOM samples incubated in sunlight, there is more bleaching at longer wavelengths than at short wavelengths (Twardowski \& Donaghay, 2002). Hence, the exposure of Lake Namtso to a high flux of solar radiation likely leads to an intensive photoinduced degradation of CDOM absorption at longer wavelengths, which combined with a low CDOM abundance, results in a very low absorption at wavelengths in the visible spectral region. Furthermore, since Lake Namtso has no outflow river, a long water retention time is likely to expose CDOM in the lake to extensive photo-degradation, resulting in low CDOM absorption.

The CDOM absorption coefficient at $440 \mathrm{~nm}$ $\left[a_{\mathrm{g}}(440)\right]$ is commonly used to characterize the concentration of CDOM in different water types, and hence it is important to determine $a_{\mathrm{g}}(440)$ accurately. Figure $4 \mathrm{~b}$ shows that $a_{\mathrm{g}}(440)$ values derived by using different wavelength ranges for fitting, i.e., 280-500 versus $350-500 \mathrm{~nm}$, are significantly different. Therefore, it is important to choose the right wavelength range to determine the absorption coefficient at a specific wavelength. The range of values for $a_{\mathrm{g}}(440)$ $\left(0.015-0.065 \mathrm{~m}^{-1}\right)$ for Lake Namtso is quite similar to that found for Qinghai Lake $\left(0.035-0.056 \mathrm{~m}^{-1}\right.$ ) (Zhou et al., 2005), which is the largest lake on the TP at an altitude of 3,200 $\mathrm{m}$ above sea level. The mean values for $a_{g}(440)$ derived for these two lakes are almost the same $\left(0.041\right.$ versus $\left.0.042 \mathrm{~m}^{-1}\right)$. Both the values of $a_{\mathrm{g}}(320)$ and $a_{\mathrm{g}}(440)$ found in Lake Namtso are close to the values found in alpine lakes with catchment areas having less than $5 \%$ of sparse pine trees (i.e., exposed rock), and are generally lower than the values found in mountain lakes surrounded by alpine meadows in the Tyrolian Alps (Austria and Italy) (Laurion et al., 2000).

The derived values of $S_{280-500}$ for Lake Namtso water are generally higher than corresponding values for lakes in the Tyrolian Alps and the Pyrenees, where $S_{295-400}$ was found to range from 10.8 to 19.9 $\mu \mathrm{m}^{-1}$ (Laurion et al., 2000), and for lakes on the Yungui Plateau, where the mean value of $S_{280-500}$ was found to range from 14.64 to $23.18 \mu \mathrm{m}^{-1}$ (Zhang et al., 2010). Lake Namtso $\left[4,718 \mathrm{~m}, 30^{\circ} 30^{\prime} \mathrm{N}-\right.$ $\left.30^{\circ} 56^{\prime} \mathrm{N}\right]$ is located at a higher altitude and lower latitude than the lakes in the Tyrolian Alps and the Pyrenees $\left[422-2,799 \mathrm{~m}, 42^{\circ} 32^{\prime} \mathrm{N}-47^{\circ} 48^{\prime} \mathrm{N}\right.$ ] (Laurion et al., 2000) and is exposed to stronger solar radiation, which causes photobleaching of CDOM, resulting in loss of absorption and increase of the spectral slope $S$ (Twardowski \& Donaghay, 2002). At the Yungui Plateau, the altitude range of the lakes included in the study (Zhang et al., 2010) varied between 1,516 and $4,591 \mathrm{~m}$ and the latitude range varied between $24.133^{\circ} \mathrm{N}$ and $30.320^{\circ} \mathrm{N}$, implying that the strength of the solar radiation compared with that at Lake Namtso could be greater or smaller depending on the 
location. The difference between the $S$ values for these lakes and those of Lake Namtso can be partly explained by the fact that the $S$ value depends on the wavelength range for which it is derived (Stedmon et al., 2000; Twardowski et al., 2004). According to Twardowski et al. (2004), about three quarters of the variability in the $S$ values found in the literature can be attributed to different spectral ranges used in different studies. The derived mean value for $S_{350-500}$ for Lake Namtso is lower than that for Qinghai lake $\left(S_{380-550}=\right.$ $0.0206 \mathrm{~nm}^{-1}$ ) (Zhou et al., 2005) and in the range of $S$ values derived for lakes located in the Tyrolian Alps and the Pyrenees $\left(S_{370-500}\right.$ varied between 7.1 and 18.9 $\mu \mathrm{m}^{-1}$ ) (Laurion et al., 2000). The Lake Namtso mean value is also close to the mean value of $0.0151 \mathrm{~nm}^{-1}$ derived for Lake Taihu in China (Ma et al., 2006) when similar wavelength ranges were used for fitting.

The choice of a suitable wavelength range for determining the slope $S$ and the absorption coefficient at a given wavelength is critical for a CDOM sample having a log-transformed absorption spectrum that does not follow a straight line, such as in our case. This kind of behavior is found also in other water bodies (Twardowski et al., 2004; Helms et al., 2008). The mean $S_{\mathrm{R}}$ value for Lake Namtso is in the range of $S_{\mathrm{R}}$ values derived for lakes on the Yungui Plateau (Zhang et al., 2010), but higher than the values presented in Table 2 for samples marked 'init' (implying no sample treatment involved) in a paper by Helms et al. (2008). The $S_{\mathrm{R}}$ value may also be used to indicate the change of the spectral slope over a wide spectral range. Thus, for a perfect exponential curve, $S_{\mathrm{R}}$ is equal to 1 , while, for an approximately exponential curve with a changing spectral slope, $S_{\mathrm{R}}$ will deviate from 1. For CDOM samples having $S_{R}$ values that deviate significantly from 1 , such as in our case, special caution must to be taken when determining the absorption coefficient at $440 \mathrm{~nm}\left[a_{\mathrm{g}}(440)\right]$ or $443 \mathrm{~nm}\left[a_{\mathrm{g}}(443)\right]$, which is one of the commonly retrieved parameters used to characterize CDOM samples from different water types.

This mean value of the TSM absorption coefficient at $440 \mathrm{~nm}\left[a_{p}(440)\right]$ for Lake Namtso water is much lower than that found for water in lakes on the Yunnan Plateau in China (Zhang et al., 2009). Generally, the smaller peaks and shoulders around 440 and $676 \mathrm{~nm}$ for the samples collected in late July 2013 (red curves) compared to those for the samples collected in the middle of August 2014 (black curves) implies either a possible seasonal variation of the Chl- $a$ concentration or a variation between the two years. Peaks found in the UV spectral region between 310 and $370 \mathrm{~nm}$ and in the visible region between 600 and $640 \mathrm{~nm}$ in the absorption spectra for most samples from Lake Namtso indicate the presence of other pigments than Chl- $a$. Lake Namtso is an oligotrophic lake, so that the relative abundance of accessory pigments (at least nonphotosynthetic carotenoids) is high compared to that in mesotrophic or eutrophic waters (Bricaud et al., 2004).

The peaks between 310 and $370 \mathrm{~nm}$ in Fig. $6 \mathrm{~b}$ might be due to absorption by mycosporine-like amino acids (MAAs), which have been found in phytoplankton from several mountain lakes (Tartarotti \& Sommaruga, 2006; Ficek et al., 2013). They play a role in protecting alpine aquatic organisms from UV radiation. For the samples collected in late July 2013, the peaks in the range of $310-370 \mathrm{~nm}$ decrease as the distance from the river mouth increases, indicating that the source of the peaks is likely to come from river discharge. Also, these peaks decreased as the water depth increased, indicating a vertical distribution of MAAs. A similar vertical distribution of MAAs was observed in other mountain lakes (Tartarotti \& Sommaruga, 2006; Ficek et al., 2013). In a 15-month study of an alpine lake, Tartarotti \& Sommaruga (2006) found that during summer the content of MAAs in phytoplankton decreased with depth.

The absorption shoulders between 600 and $640 \mathrm{~nm}$ in Fig. $6 \mathrm{~b}$ are probably due to absorption by phycobiliproteins, which are major light-harvesting pigments found in several types of algae. Thus, phycocyanin found in cyanobacteria has an absorption peak at $620 \mathrm{~nm}$ (Patel et al., 2005; Kirk, 2011). A similar peak due to absorption by cyanobacteria picoplankton sampled in Lake Biwa, has been reported by Maeda et al. (1992). This is supported by an observation by Yuan et al. (2002) regarding the phytoplankton community composition in Lake Namtso. They found that Bacillariophyta (diatoms) were dominant at the southern bank, whereas Chlorophyta (green algae) and Cyanophyta ( cyanobacteria) were dominant in the eastern part of Lake Namtso. Furthermore, Liu et al. (2010) found cyanobacteria among several other bacteria in Lake Namtso. 


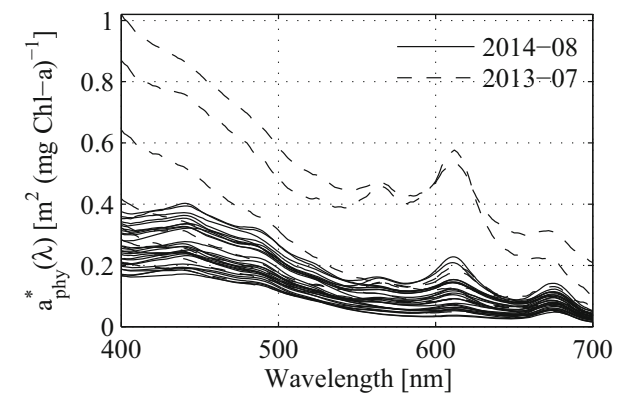

Fig. 7 Spectra of Chl- $a$ specific absorption by phytoplankton for Lake Namtso in July (dashed curves) and in August (solid curves)

The absorption spectra for phytoplankton samples collected in late July 2013 from Lake Namtso (as shown in Fig. 6b red curves) consistently decrease exponentially as the wavelength increases from 400 to $550 \mathrm{~nm}$. Binding et al. (2008) observed such atypical phytoplankton absorption spectra for Lake Erie, and they argued that it is due to absorption by colloidal or particle-bound DOM rather than phytoplankton.

At three different depths in Lake Namtso the measured Chl- $a$ concentrations were so low $(<0.01$ $\mu \mathrm{gl}^{-1}$ ) that, in view of measurement errors, they were excluded in the computation of the spectral Chl- $a$ specific absorption coefficient of phytoplankton $a_{\text {phy }}^{*}(\lambda)$ shown in Fig. 7 . In most cases, $a_{\text {phy }}^{*}(\lambda)$ for samples collected in July and August were quite similar. The values of the Chl- $a$ specific absorption coefficient of phytoplankton at $440 \mathrm{~nm}\left[a_{\text {phy }}^{*}(440)\right]$ were found to vary in the range $0.17-0.87 \mathrm{~m}^{2} \mathrm{mg}^{-1}$ with a mean value of $0.31 \mathrm{~m}^{2} \mathrm{mg}^{-1}$; while at $675 \mathrm{~nm}$, it varied between 0.047 and $0.31 \mathrm{~m}^{2} \mathrm{mg}^{-1}$ with a mean value of $0.095 \mathrm{~m}^{2} \mathrm{mg}^{-1}$. The maximum and the mean values reported here for Lake Namtso are much higher than those for oceanic water (Bricaud et al., 1995) as well as for Lake Erie (maximum values of $a_{\text {phy }}^{*}(440)$ and $a_{\mathrm{phy}}^{*}(670)$ were 0.51 and $0.16 \mathrm{~m}^{2} \mathrm{mg}^{-1}$, respectively) (Binding et al., 2008). The higher values for Lake Namtso compared to those for Lake Erie can be attributed partly to the fact that the measured Chl$a$ concentrations in our study did not include phaeopigments, whereas they were included in the study of Binding et al. (2008). Lake Namtso is an oligotrophic lake, in which the average cell size is small, implying that the package effect tends to be small. Also, Fig. $6 \mathrm{~b}$ indicates the presence of accessory pigments.

The derived range and mean value of $S_{\mathrm{NAP}}$ for Lake Namtso water are close to those derived for Lake Taupo [0.008-0.012 with a mean value of 0.009 $\mathrm{nm}^{-1}$ (Belzile et al., 2004)], another large oligotrophic lake, and also to oceanic water (Bricaud et al., 1998). The mean value for $S_{\mathrm{NAP}}$ for Lake Namtso water is slightly lower than the corresponding mean value derived for European coastal water (Babin et al., 2003).

Figure 8 shows ternary diagrams of the percentage contributions to the absorption coefficient $\left(a_{\text {sum }}=a_{g}+a_{\text {phy }}+a_{\mathrm{NAP}}\right)$ for Lake Namtso water from CDOM $\left(a_{\mathrm{g}, \text { perc }}=\left[a_{\mathrm{g}} / a_{\text {sum }}\right] \times 100\right)$, phytoplankton $\left(a_{\text {phy,perc }}=\left[a_{\text {phy }} / a_{\text {sum }}\right] \times 100\right)$, and non-algal particles $\quad\left(a_{\mathrm{NAP}, \text { perc }}=\left[a_{\mathrm{NAP}} / a_{\text {sum }}\right] \times 100\right) \quad$ at the wavelengths of 380,443 , and $676 \mathrm{~nm}$. CDOM is seen to be the dominant absorbing component at the UV wavelength of $380 \mathrm{~nm}$ (see Fig. 8a); its contribution is

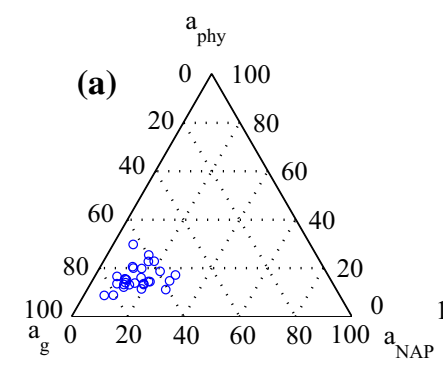

Fig. 8 Ternary diagrams showing the percentage contributions to the absorption coefficient for Lake Namtso water from $\operatorname{CDOM}\left(a_{\mathrm{g}, \text { perc }}=\left[a_{\mathrm{g}} / a_{\text {sum }}\right] \times 100\right)$, phytoplankton $\left(a_{\mathrm{phy}, \text { perc }}=\right.$ $\left.\left[a_{\text {phy }} / a_{\text {sum }}\right] \times 100\right)$, and non-algal particles $\left(a_{\text {NAP,perc }}=\right.$
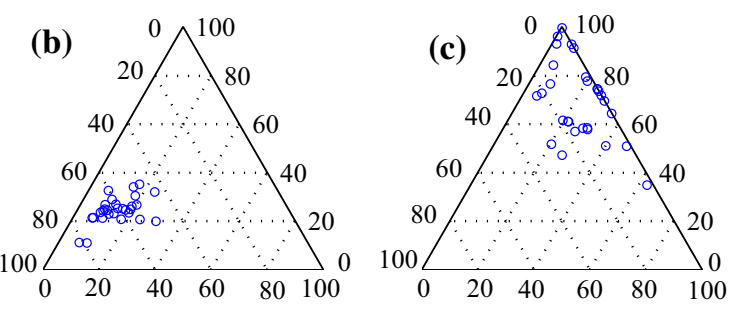

$\left.\left[a_{\mathrm{NAP}} / a_{\text {sum }}\right] \times 100\right)$, where $a_{\text {sum }}=a_{g}+a_{\text {phy }}+a_{\mathrm{NAP}}$, at a 380 $\mathrm{nm}, \mathbf{b} 443 \mathrm{~nm}$, and c $676 \mathrm{~nm}$. The percentage contributions from CDOM, phytoplankton, and non-algal particles can be read on the left, right, and bottom scales, respectively, of the triangle 
generally higher than $60 \%$. At $443 \mathrm{~nm}$, the CDOM absorption is still slightly higher than the absorption by phytoplankton and non-algal particles (see Fig. 8b). Phytoplankton is the main contributor to the absorption at $676 \mathrm{~nm}$, but in some cases non-algal particles contribute significantly. Compared to Lake Taupo (Belzile et al., 2004) (a clear-water lake similar to Lake Namtso), the relative contribution of phytoplankton to the absorption at $443 \mathrm{~nm}$ is smaller in Lake Namtso, due to lower concentrations of Chl- $a$ in Lake Namtso during our study than in Lake Taupo. The relative contributions of non-algal particles at the wavelengths of 380 and $443 \mathrm{~nm}$ are also slightly smaller in Lake Namtso (in most cases $a_{\text {NAP }}<20 \%$ ) than in Lake Taupo. The relative contribution of nonalgal particles at $676 \mathrm{~nm}$ is confined to the range 0 $20 \%$ for Lake Taupo, but varies between 0 and $60 \%$ for Lake Namtso. The difference may be attributed to lower Chl- $a$ concentrations, but higher TSM concentrations in Lake Namtso than in Lake Taupo.

\section{Conclusions}

High mountain lakes are subjected to extreme environmental conditions regarding nutrients, temperatures, and solar radiation. Zooplankton and phytoplankton in such lakes may develop strategies to adapt to such conditions. Often there is difficult access to remote lakes, and therefore basic information about optical properties is limited. In this study, we have presented measurements and analyses of the absorption properties of Lake Namtso, which is the highest located large lake on the Tibetan Plateau. The Chl- $a$ concentration is very low for Lake Namtso water, due to harsh environmental conditions. The spectral slope $S_{350-500}$ for CDOM absorption was found to vary between 0.012 and $0.023 \mathrm{~nm}^{-1}$ with a mean value of $0.015 \mathrm{~nm}^{-1}$, which is quite similar to other published values (Laurion et al., 2000; Ma et al., 2006). The spectral slope $S_{280-500}$ values for Lake Namtso are generally higher than for other lakes with a mean value of $0.036 \mathrm{~nm}^{-1}$. The mean value for $S_{280-500}$ is more than twice the mean value for $S_{350-500}$, implying a large change of the spectral slope with wavelength. The CDOM absorption in the visible range is very low and the ratio of $S_{275-295}$ to $S_{350-400}$ is large. Thus, caution must be taken when determining the absorption coefficient at $440 \mathrm{~nm}$, which is one of the parameters commonly used to characterize light absorption properties of CDOM in natural water. The CDOM absorption in the visible range is very low, as a result of poor development of the vegetation in the Lake Namtso catchment area, photo-bleaching due to strong solar radiation, and a long water retention time.

Absorption by phytoplankton at 440 and $676 \mathrm{~nm}$, typically due to absorption by Chl- $a$, was low along with very low Chl- $a$ concentrations in Lake Namtso. In addition to typical absorption peaks for phytoplankton, absorption peaks were observed in the UV spectral region, as expected for mountain lakes. Also, the phytoplankton absorption spectra had a peak in the range $600-640 \mathrm{~nm}$, which is likely to be due to absorption by phycobiliproteins. The mean and maximum values of Chl- $a$ specific absorption coefficients of phytoplankton $\left[a_{\mathrm{phy}}^{*}(\lambda)\right]$ at 440 and $675 \mathrm{~nm}$ in Lake Namtso were found to be much higher than previously reported values.

CDOM is seen to be the dominant absorbing component at the UV wavelength of $380 \mathrm{~nm}$ and the visible wavelength of $443 \mathrm{~nm}$ in this lake. At $676 \mathrm{~nm}$, phytoplankton is the main contributor to the absorption, although non-algal particles absorb significantly in some cases.

More research is needed to examine whether the approximately exponential decrease in the absorption by phytoplankton in the wavelength range from 400 to $550 \mathrm{~nm}$ is due to phytoplankton itself or due to absorption by colloidal or particle-bound DOM, as suggested by Binding et al. (2008).

Acknowledgments This work was supported by the Network for University Cooperation Tibet-Norway, the Norwegian Research Council (Project No. 209681), and the External Cooperation Program of the Chinese Academy of Sciences (Grant No. GJHZ1207).

\section{References}

Adrian, R., C. M. O’ Reilly, H. Zagarese, S. B. Baines, D. O. Hessen, W. Keller, D. M. Livingstone, R. Sommaruga, D. Straile \& E. Van Donk et al., 2009. Lakes as sentinels of climate change. Limnology and Oceanography 54: 2283-2297.

Alexandris, D., C. Varotsos, K. Y. Kondratyev \& G. Chronopoulos, 1999. On the altitude dependence of solar effective UV. Physics and Chemistry of the Earth, Part C: Solar, Terrestril \& Planetary Science 24: 515-517. 
An, Z. S., J. E. Kutzbach, W. L. Prell \& S. C. Porter, 2001. Evolution of Asian monsoons and phased uplift of the Himalaya-Tibetan Plateau since Late Miocene times. Nature 411: 62-66.

Babin, M., D. Stramski, G. M. Ferrari, H. Claustre, A. Bricaud, G. Obolensky \& N. Hoepffner, 2003. Variations in the light absorption coefficients of phytoplankton, nonalgal particles, and dissolved organic matter in coastal waters around Europe. Journal of Geophysical Research: Oceans 108(C7).

Belzile, C., W. F. Vincent \& M. Kumagai, 2002. Contribution of absorption and scattering to the attenuation of UV and photosynthetically available radiation in Lake Biwa. Limnology and Oceanography 47(1): 95-107.

Belzile, C., W. F. Vincent, C. Howard-Williams, I. Hawes, M. R. James, M. Kumagai \& C. S. Roesler, 2004. Relationships between spectral optical properties and optically active substances in a clear oligotrophic lake. Water Resources Research 40: W12512.

Binding, C. E., J. H. Jerome, R. P. Bukata \& W. G. Booty, 2008. Spectral absorption properties of dissolved and particulate matter in Lake Erie. Remote Sensing of Environment 112: 1702-1711.

Blumthaler, M., W. Ambach \& W. Rehwald, 1992. Solar UV-A and UV-B radiation fluxes at two alpine stations at different altitudes. Theoretical and Applied Climatology 46: 39-44.

Bricaud, A., A. Morel \& L. Prieur, 1981. Absorption by dissolved organic matter of the sea (yellow substance) in the UV and visible domains. Limnology and Oceanography 26: 43-53.

Bricaud, A., M. Babin, A. Morel \& H. Claustre, 1995. Variability in the chlorophyll-specific absorption coefficients of natural phytoplankton: analysis and parameterization. Journal of Geophysical Research: Oceans 100: 13321-13332.

Bricaud, A., A. Morel, M. Babin, K. Allali \& H. Claustre, 1998. Variations of light absorption by suspended particles with chlorophyll a concentration in oceanic (Case 1) waters: analysis and implications for bio-optical models. Journal of Geophysical Research: Oceans 103: 31033-31044

Bricaud, A., H. Claustre, J. Ras \& K. Oubelkheir, 2004. Natural variability of phytoplanktonic absorption in oceanic waters: influence of the size structure of algal populations. Journal of Geophysical Research: Oceans 109: C11.

Brinkmann, T., D. Sartorius \& F. H. Frimmel, 2003. Photobleaching of humic rich dissolved organic matter. Aquatic Sciences 65: 415-424.

Davies-Colley, R. J., W. N. Vant \& G. J. Latimer, 1984. Optical characterisation of natural waters by PAR measurement under changeable light conditions. New Zealand Journal of Marine and Freshwater Research 18: 455-460.

Del Vecchio, R. \& N. V. Blough, 2002. Photobleaching of chromophoric dissolved organic matter in natural waters: kinetics and modeling. Marine Chemistry 78: 231-253.

Dorji, T., Ø. Totland, S. R. Moe, K. A. Hopping, J. B. Pan \& J. A. Klein, 2013. Plant functional traits mediate reproductive phenology and success in response to experimental warming and snow addition in Tibet. Global Change Biology 19: 459-472.

Ficek, D., J. Dera \& B. Wozniak, 2013. UV absorption reveals mycosporine-like amino acids (MAAs) in Tatra mountain lake phytoplankton. Oceanologia 55: 599-609.
Hahn, D. G. \& S. Manabe, 1975. The role of mountains in the South Asian monsoon circulation. Journal of the Atmospheric Sciences 32: 1515-1541.

Hargreaves, B. R., S. F. Girdner, M. W. Buktenica, R. W. Collier, E. Urbach \& G. L. Larson, 2007. Ultraviolet Radiation and Bio-optics in Crater Lake, Oregon. In: Long-term Limnological Research and Monitoring at Crater Lake, Oregon, Springer, Netherlands: 107-140

Helbling, E. W., V. E. Villafañe, A. G. Buma, M. Andrade \& F. Zaratti, 2001. DNA damage and photosynthetic inhibition induced by solar ultraviolet radiation in tropical phytoplankton (Lake Titicaca, Bolivia). European Journal of Phycology 36: 157-166.

Helms, J. R., A. Stubbins, J. D. Ritchie, E. C. Minor, D. J. Kieber \& K. Mopper, 2008. Absorption spectral slopes and slope ratios as indicators of molecular weight, source, and photobleaching of chromophoric dissolved organic matter. Limnology and Oceanography 53: 955-969.

Jeffrey, S. W. \& G. F. Humphrey, 1975. New spectrophotometric equations for determining chlorophylls a, b, c1 and c2 in higher plants, algae and natural phytoplankton. Biochemistrie Physiologie Pflanzen 167: 191-194.

Jiang, J. H. \& Q. Huang, 2004. Distribution and variation of lakes in Tibetan Plateau and their comparison with lakes in other part of China (in Chinese). Water Resources Protection 6: 24-27.

Kang, S. C., Y. P. Yang, L. P. Zhu \& Y. M. Ma, 2011. Modern Environmental Processes and Changes in the Nam Co Basin, Tibetan Plateau. Meteorological Press, Beijing.

Kirk, J. T. O., 2011. Light and Photosynthesis in Aquatic Ecosystems, 3rd ed. Cambridge University Press, Cambridge.

Kropáček, J., F. Maussion, F. Chen, S. Hoerz \& V. Hochschild, 2013. Analysis of ice phenology of lakes on the Tibetan Plateau from MODIS data. The Cryosphere 7: 287-301.

Laurion, I., M. Ventura, J. Catalan, R. Psenner \& R. Sommaruga, 2000. Attenuation of ultraviolet radiation in mountain lakes: factors controlling the among-and withinlake variability. Limnology and Oceanography 45: 1274-1288.

Liu, X. B., T. D. Yao, S. C. Kang, N. Z. Jiao, Y. H. Zeng \& Y. Q. Liu, 2010. Bacterial community of the Largest Oligosaline Lake, Namco on the Tibetan Plateau. Geomicrobiology Journal 27: 669-682.

Liu, Y. Q., T. D. Yao, L. P. Zhu, N. Z. Jiao, X. B. Liu, Y. H. Zeng \& H. C. Jiang, 2009. Bacterial diversity of freshwater alpine lake Puma Yumco on the Tibetan Plateau. Geomicrobiology Journal 26: 131-145.

Ma, R., J. Tang, J. Dai, Y. Zhang \& Q. Song, 2006. Absorption and scattering properties of water body in Taihu Lake, China: absorption. International Journal of Remote Sensing 27: 4277-4304.

Maeda, H., A. Kawai \& M. M. Tilzer, 1992. The water bloom of cyanobacterial picoplankton in Lake Biwa, Japan. Hydrobiologia 248: 93-103.

Mitamura, O., Y. Seike, K. Kondo, N. Goto, K. Anbutsu, T. Akatsuka, M. Kihira, T. Q. Tsering \& M. Nishimura, 2003. First investigation of ultraoligotrophic alpine Lake Puma Yumco in the pre-Himalayas, China. Limnology 4: 167-175.

Norsang, G., L. Kocbach, W. Tsoja, J. J. Stamnes, A. Dahlback \& P. Nema, 2009. Ground-based measurements and 
modeling of solar UV-B radiation in Lhasa, Tibet. Atmospheric Environment 43: 1498-1502.

Norsang, G., L. Kocbach, J. J. Stamnes, W. Tsoja \& N. Pingcuo, 2011. Spatial distribution and temporal variation of solar UV radiation over the Tibetan Plateau. Applied Physics Research 3: 37-46.

Norsang, G., Y. C. Chen, N. Pingcuo, A. Dahlback, Ø. Frette, B. Kjeldstad, B. Hamre, K. Stamnes \& J. J. Stamnes, 2014. Comparison of ground-based measurements of solar UV radiation at four sites on the Tibetan Plateau. Applied Optics 53: 736-747.

Parry, M. L., 2007. Climate change 2007: impacts, adaptation and vulnerability. Working Group II Contribution to the Fourth Assessment Report of the IPCC Intergovernmental Panel on Climate Change, Vol. 4. Cambridge University Press

Patel, A., S. Mishra, R. Pawar \& P. K. Ghosh, 2005. Purification and characterization of C-phycocyanin from cyanobacterial species of marine and freshwater habitat. Protein Expression and Purification 40: 248-255.

Rose, K. C., C. E. Williamson, S. G. Schladow, M. Winder \& J. T. Oris (2009) Patterns of spatial and temporal variability of UV transparency in Lake Tahoe, California-Nevada. Journal of Geophysical Research: Biogeosciences (2005-2012) 114: G00D03.

Sommaruga, R., 2001. The role of solar UV radiation in the ecology of alpine lakes. Journal of Photochemistry and Photobiology B: Biology 62: 35-42.

Sommaruga-Wögrath, S., K. A. Koinig, R. Schmidt, R. Sommaruga, R. Tessadri \& R. Psenner, 1997. Temperature effects on the acidity of remote alpine lakes. Nature 387 : 64-67.

Stedmon, C. A., S. Markager \& H. Kaas, 2000. Optical properties and signatures of chromophoric dissolved organic matter (CDOM) in Danish coastal waters. Estuarine, Coastal and Shelf Science 51: 267-278.

Tahoe Environmental Research Center, 2015. Tahoe: State of the lake report. University of California, Davis.

Tartarotti, B. \& R. Sommaruga, 2006. Seasonal and ontogeetic changes of mycosporine-like amino acids in planktonic organisms from an alpine lake. Limnology and Oceanography 51: 1530-1541.

Tartarotti, B., S. Cabrera, R. Psenner \& R. Sommaruga, 1999. Survivorship of Cyclops Abyssorum Tatricus (Cyclopoida, Copepoda) and Boeckella Gracilipes (Calanoida, Copepoda) under ambient levels of solar UVB radiation in two high-mountain lakes. Journal of Plankton Research 21: 549-560.

Tassan, S. \& G. M. Ferrari, 2002. A sensitivity analysis of the transmittance-reflectance method for measuring light absorption by aquatic particles. Journal of Plankton Research 24: 757-774.

Tilstone, G. H., G. F. Moore, K. Sørensen, R. Doerfeer, R. Røttgers, K. D. Ruddick, R. Pasterkamp \& P. V. Jørgensen, 2002. Regional validation of MERIS chlorophyll products in North Sea coastal waters. REVAMP Methodologies EVGI-CT-2001-00049.

Twardowski, M. S. \& P. L. Donaghay, 2002. Photobleaching of aquatic dissolved materials: absorption removal, spectral alteration, and their interrelationship. Journal of Geophysical Research: Oceans 107(C8).
Twardowski, M. S., E. Boss, J. M. Sullivan \& P. L. Donaghay, 2004. Modeling the spectral shape of absorption by chromophoric dissolved organic matter. Marine Chemistry 89: 69-88.

Vinebrooke, R. D. \& P. R. Leavitt, 1996. Effects of ultraviolet radiation on periphyton in an alpine lake. Limnology and Oceanography 41: 1035-1040.

Vollenweider, R. A., 1982. Eutrophication of waters: monitoring, assessment and control. Organisation for Economic Co-operation and Development (OECD).

Wan, W., P. F. Xiao, X. Z. Feng, H. Li, R. H. Ma \& H. T. Duan, 2010. Remote sensing analysis for changes of lakes in the southeast of Qiangtang area, Qinghai-Tibet Plateau in recent 30 years (in Chinese). Journal of Lake Sciences 22: 874-881.

Wang, G. X., Y. B. Wang, Y. S. Li \& H. Y. Cheng, 2007a. Influences of alpine ecosystem responses to climatic change on soil properties on the Qinghai-Tibet Plateau, China. Catena 70: 506-514.

Wang L. H., A. X. Lu, T. D. Yao \& N. L. Wang, 2007b. The study of typical glaciers and lakes fluctuations using remote sensing in Qinghai-Tibetan Plateau. IEEE International of Geoscience and Remote Sensing Symposium, IGARSS: 4526-4529.

Wang, J. B., L. P. Zhu, G. Daut, J. T. Ju, X. Lin, Y. Wang \& X. L. Zhen, 2009. Investigation of bathymetry and water quality of Lake Nam Co, the largest lake on the central Tibetan Plateau, China. Limnology 10: 149-158.

Wang, S. L., H. J. Jin, S. X. Li \& L. Zhao, 2000. Permafrost degradation on the Qinghai-Tibet Plateau and its environmental impacts. Permafrost and Periglacial Processes 11: 43-53.

Williamson, C. E., W. Dodds, T. K. Kratz \& M. A. Palmer, 2008. Lakes and streams as sentinels of environmental change in terrestrial and atmospheric processes. Frontiers in Ecology and the Environment 6: 247-254.

Wright, S.W., 1991. Improved HPLC method for the analysis of chlorophylls and carotenoids from marine phytoplankton. Marine Ecology Progress Series 77: 183-196.

Wu, Q. L. L., G. Zwart, M. Schauer, M. P. Kamst-van Agterveld \& M. W. Hahn, 2006. Bacterioplankton community composition along a salinity gradient of sixteen high-mountain lakes located on the Tibetan Plateau, China. Applied and Environmental Microbiology 72: 5478-5485.

Ye, Q. H., Q. F. Wei, V. Hochschild \& C. R. Duguay, 2011. Integrated observations of lake ice at Nam Co on the Tibetan Plateau from 2001 to 2009. In: IEEE International on Geoscience and Remote Sensing Symposium (IGARSS), 2011: 3217-3220.

Yentsch, C. S., 1962. Measurement of visible light absorption by particulate matter in the ocean. Limnology and Oceanography 7: 207-217.

Yuan, J., J. X. Gao, X. G. Lu \& K. L. Chen, 2002. Assessment on wetland resources in Namucuo and countermeasures for conservation and rational use (in Chinese). Resources Science 24: 29-34.

Zhang, Y. L., E. L. Zhang \& M. L. Liu, 2009. Spectral absorption properties of chromophoric dissolved organic matter and particulate matter in Yunnan Plateau lakes (in Chinese). Journal of Lake Sciences 21: 255-263. 
Zhang, Y. L., E. L. Zhang, Y. Yin, M. A. Van Dijk, L. Q. Feng, Z. Q. Shi, M. L. Liu \& B. Q. Qin, 2010. Characteristics and sources of chromophoric dissolved organic matter in lakes of the Yungui Plateau, China, differing in trophic state and altitude. Limnology and Oceanography 55: 2645-2659.
Zhou, H. L., J. H. Zhu, T. J. Li \& X. Y. Wang, 2005. The analysis of water color element absorb spectral characteristic in Qinghai Lake (in Chinese). Ocean Technology 24: 55-58.

Zhou, X. J., W. L. Li, L. X. Chen \& Y. Liu, 2006. Study on ozone change over the Tibetan Plateau. Acta Meteorologica Sinica 20: 129-143. 